\title{
Rapidly developing vesicular eruption
}

\section{The patient's previously diagnosed dermatologic condition, paired with her recent exposure history, led to the diagnosis in this case.}

A 23-MONTH-OLD GIRL with a history of wellcontrolled atopic dermatitis was admitted to the hospital with fever and a widespread vesicular eruption of 2 days' duration. Two days prior to admission, the patient had 3 episodes of nonbloody diarrhea and redness in the diaper area. The child's parents reported that the red areas spread to her arms and legs later that day, and that she subsequently developed a fever, cough, and rhinorrhea. She was taken to an urgent care facility where she was diagnosed with vulvovaginitis and an upper respiratory infection; amoxicillin was prescribed. Shortly thereafter, the patient developed more lesions in and around the mouth, as well as on the trunk, prompting the parents to bring her to the emergency department.

The history revealed that the patient had spent time with her aunt and cousins who had "red spots" on their palms and soles. The patient's sister had a flare of "cold sores," about 2 weeks prior to the current presentation. The patient had received a varicella zoster virus (VZV) vaccine several months earlier.

Physical examination was notable for an uncomfortable infant with erythematous macules on the bilateral palms and soles and an erythematous hard palate. The child also had scattered vesicles on an erythematous base with confluent crusted plaques on her lips, perioral skin (FIGURE 1A), abdomen, back, buttocks, arms, legs (FIGURE 1B), and dorsal aspects of her hands and feet.

\section{O WHAT IS YOUR DIAGNOSIS? \\ O HOW WOULD YOU TREAT THIS PATIENT?}

Shane M. Swink, DO, MS; Timmie R. Sharma, MD Kevin D. Cooper, MD Division of Dermatology, Lehigh Valley Health Network, Allentown, PA (Dr. Swink); Department of Dermatology, University Hospitals Cleveland Medical Center, OH (Drs. Sharma and Cooper)

\section{M shanesw@pcom.edu}

DEPARTMENT EDITOR Richard P. Usatine, MD University of Texas Health at San Antonio

The authors reported no potential conflict of interest relevant to this article.

doi: $10.12788 / \mathrm{jfp} .0080$

\section{FIGURE 1}

\section{3-month-old girl with vesicles on an erythematous base}
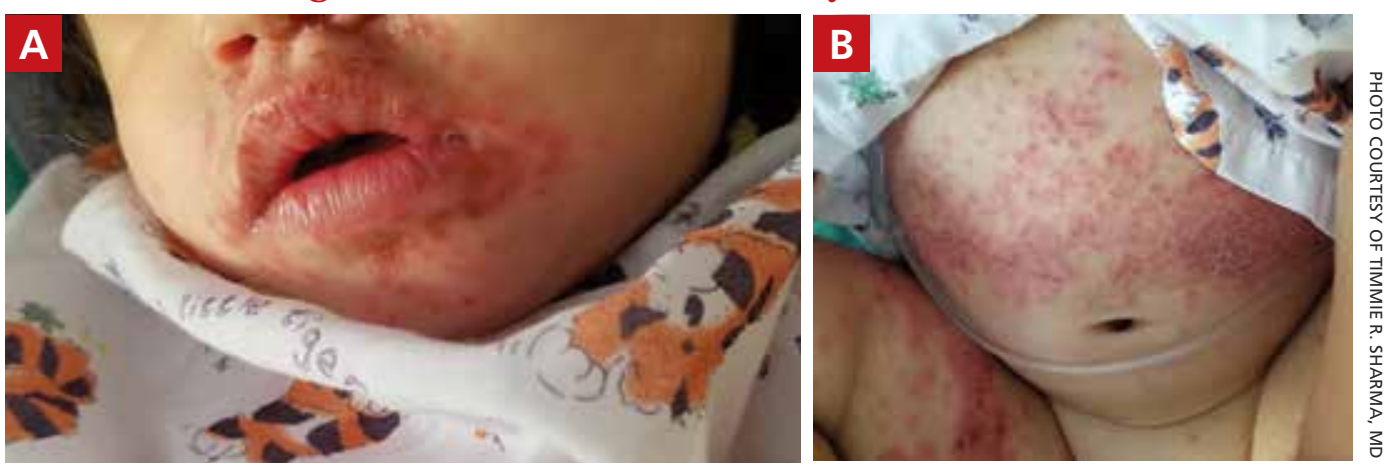


\section{,}

Prompt diagnosis and treatment for eczema coxsackium is critical to prevent unnecessary antiviral therapy.

\section{Diagnosis:}

\section{Eczema coxsackium}

Given the history of atopic dermatitis; prodromal diarrhea/rhinorrhea; papulovesicular eruption involving areas of prior dermatitis as well as the palms, soles, and mouth; recent contacts with suspected hand-foot-mouth disease (HFMD); and history of VZV vaccination, the favored diagnosis was eczema coxsackium.

I Eczema coxsackium is an atypical form of HFMD that occurs in patients with a history of eczema. Classic HFMD usually is caused by coxsackievirus A16 or enterovirus 71, while atypical HFMD often is caused by coxsackievirus A6. ${ }^{1,2,3}$ Patients with HFMD present with painful oral vesicles and ulcers and a papulovesicular eruption on the palms, soles, and sometimes the buttocks and genitalia. Patients may have prodromal fever, fussiness, and diarrhea. Painful oral lesions may result in poor oral intake. ${ }^{1,2}$

\section{Differential includes viral eruptions}

Other conditions may manifest similarly to eczema coxsackium and must be ruled out before initiating proper treatment.

I Eczema herpeticum (EH). In atypical HFMD, the virus can show tropism for active or previously inflamed areas of eczematous skin, leading to a widespread vesicular eruption, which can be difficult to distinguish from EH. ${ }^{1}$ Similar to EH, eczema coxsackium does not exclusively affect children with atopic dermatitis. It also has been described in adults and patients with Darier disease, incontinentia pigmenti, and epidermolytic ichthyosis. ${ }^{4-6}$

In cases of vesicular eruptions in eczema patients, it is imperative to rule out EH. One prospective study of atypical HFMD compared similarities of the conditions. Both have a predilection for mucosa during primary infection and develop vesicular eruptions on cutaneous eczematous skin. ${ }^{1}$ One key difference between eczema coxsackium and $\mathrm{EH}$ is that $\mathrm{EH}$ tends to produce intraoral vesicles beyond simple erythema; it also tends to predominate in the area of the head and neck. ${ }^{7}$

I Eczema varicellicum has been reported, and it has been suggested that some cases of EH may actually be caused by VZV as the 2 are clinically indistinguishable and less than half of $\mathrm{EH}$ cases are diagnosed with laboratory confirmation. ${ }^{8}$

\section{Confirm Dx before you treat}

To guide management, cases of suspected eczema coxsackium should be confirmed, and HSV/VZV should be ruled out. ${ }^{9}$ Testing modalities include swabbing vesicular fluid for enterovirus polymerase chain reaction (PCR) analysis (preferred modality), oropharyngeal swab up to 2 weeks after infection, or viral isolate from stool samples up to 3 months after infection., ${ }^{2,3}$

\section{Treatment for eczema coxsackium} involves supportive care such as intravenous (IV) hydration and antipyretics. Some studies show potential benefit with IV immunoglobulin in treating severe HFMD, while other studies show the exacerbation of widespread HFMD with this treatment. ${ }^{7,10}$

Prompt diagnosis and treatment for eczema coxsackium is critical to prevent unnecessary antiviral therapy and to help guide monitoring for associated morbidities including Gianotti-Crosti syndrome-like eruptions, purpuric eruptions, and onychomadesis.

I Our patient. Because EH was in the differential, our patient was started on empiric IV acyclovir $10 \mathrm{mg} / \mathrm{kg}$ every 8 hours while test results were pending. In addition, she received acetaminophen, IV fluids, gentle sponge baths, and diligent emollient application. Scraping from a vesicle revealed negative herpes simplex virus 1/2 PCR, negative VZV direct fluorescent antibody, and a positive enterovirus PCR-confirming the diagnosis of eczema coxsackium. Interestingly, a viral culture was negative in our patient, consistent with prior reports of enterovirus being difficult to culture. ${ }^{11}$

With confirmation of the diagnosis of eczema coxsackium, the IV acyclovir was discontinued, and symptoms resolved after 7 days.

JFP

CORRESPONDENCE

Shane M. Swink, DO, MS, Division of Dermatology,

1200 South Cedar Crest Boulevard, Allentown, PA 18103; shanesw@pcom.edu

\section{References}

1. Neri I, Dondi A, Wollenberg A, et al. Atypical forms of hand, foot, and mouth disease: a prospective study of 47 Italian children. $P e$ - 
diatr Dermatol. 2016;33:429-437.

2. Nassef C, Ziemer C, Morrell DS. Hand-foot-and-mouth disease: a new look at a classic viral rash. Curr Opin Pediatr. 2015;27: 486-491.

3. Horsten H, Fisker N, Bygu, A. Eczema coxsackium caused by coxsackievirus A6. Pediatr Dermatol. 2016;33:230-231.

4. Jefferson J, Grossberg A. Incontinentia pigmenti coxsackium. Pediatr Dermatol. 2016;33:E280-E281.

5. Ganguly S, Kuruvila S. Eczema coxsackium. Indian J Dermatol. 2016;61:682-683.

6. Harris $\mathrm{P}$, Wang AD, Yin M, et al. Atypical hand, foot, and mouth disease: eczema coxsackium can also occur in adults. Lancet In fect Dis. 2014;14:1043.
7. Wollenberg A, Zoch C, Wetzel S, et al. Predisposing factors and clinical features of eczema herpeticum: a retrospective analysis of 100 cases. J Am Acad Dermatol. 2003;49:198-205.

8. Austin TA, Steele RW. Eczema varicella/zoster (varicellicum). Clin Pediatr. 2017;56:579-581.

9. Leung DYM. Why is eczema herpeticum unexpectedly rare? Antiviral Res. 2013;98:153-157.

10. Cao RY, Dong DY, Liu RJ, et al. Human IgG subclasses against enterovirus type 71: neutralization versus antibody dependent enhancement of infection. PLoS One. 2013;8:E64024.

11. Mathes EF, Oza V, Frieden IJ, et al. Eczema coxsackium and unusual cutaneous findings in an enterovirus outbreak. Pediatrics. 2013;132:149-157. 